by the assignor. ${ }^{24}$ Overruling of the Graham case would obviate the need for such revision. ${ }^{25}$ But if the Court of Claims upholds the Comptroller-General, Congress should act to prevent a drying up of assignment financing of defense contracts.

\title{
TREBLE DAMAGE TIME LIMITATIONS: FEDERALISM RAMPANT
}

THE application of time limitations in treble damage actions under the federal antitrust laws has been a burdensome irrationality. In the Chattanooga case the Supreme Court held that Congress' failure to provide a federal statute of limitations ${ }^{1}$ makes limitations a matter of local law. ${ }^{2}$ With a steadily increasing volume of private antitrust litigation, federal courts have

24. H.R. 2947, 82d Cong., 1st Sess. (1951), to amend the Assignment of Claims Act, has received the support of the American Bankers Association, the guaranteeing agencies, and the Federal Reserve Bank. See BANking 113 (February, 1951). The American Bankers Association has proposed an amendment which would specifically disallow reductions for renegotiation, fines, penalties, taxes, and social security contributions. Hearings before House Judiciary Committee on H.R. 2947, 82d Cong., 1st Sess. (March 7, 1951) (statement of Francis H. Beam, member, American Bankers Association Credit Policy Commission).

25. The Central Bank filed an appeal to the United States Court of Claims on Sept. 22, 1950. But reversal of the Comptroller-General's decision seems highly unlikely. Cf. Rhode Island Discount Co. v. United States, 94 F. Supp. 669, 676 (Ct. Cl. 1951) (similar set-off called allowable).

1. No limitation was included in the Sherman Act. 26 STAT. 209 (1890), 15 U.S.C. $\$ 1$ et seq. (1946). "The Senate Judiciary Committee, in reporting the original Clayton Act, included a 6-year statute of limitations, but the provision later disappeared in the final drafting of the Clayton Act." Hearings before Subcommittee of the House Committee of the Judiciary on H.R. 7905, 81st Cong., 2d Sess. 24 (1950) (testimony of George B. Burnham). See $\$ 6$ of the Clayton Act as introduced in the Senate, 51 Cong. REc. 12797 (1914).

2. Chattanooga Foundry \& Pipe Works v. Atlanta, 203 U.S. 390 (1906). The Court, after deciding that the claim for treble damages was not a penalty within the meaning of a federal statute placing a five-year limitation on suits for penalties and forfeitures, ruled that a ten-year Tennessee limitation on ". . . all other cases not expressly provided for . . ." governed. Id. at 398.

The "local law" doctrine has had a long history. The Chattanooga decision grew out of Campbell v. Haverhill, 155 U.S. 610 (1895) (six year Massachusetts limitation on tort actions applied to federal action for patent infringement in absence of a federal statute of limitations), which in turn was based on the Rules of Decision Act. 1 Stat. 73 (1789), as amended 28 U.S.C. 1652 (1950). This Act provides that "the laws of the several states, except where the . . . Acts of Congress otherwise require or provide, shall be regarded as rules of decision in trials at common law [changed in 1948 to read 'civil actions'] in the courts of the United States, in cases where they apply." For a discussion of the doctrinal basis of the Chattanooga decision, see Note, 49 Y ALE L. J. 738, 742 et seq. (1940).

State statutes of limitation govern treble damage actions brought under subsequent antitrust laws as well as under the Sherman Act. E.g., Kentucky-Tennessee Light \& Power Co. v. Nashville Coal Co., 37 F. Supp. 728 (W.D. Ky. 1941) (Robinson-Patman Act); Williamson v. Columbia Gas \& Electric Corp., 27 F. Supp. 198 (D. Del. 1939) (Clayton Act). 
had to construe no less than sixteen state statutes providing for periods ranging from one to ten years from the time the damage was incurred. ${ }^{3}$

The fact that there are forty-eight states and the District of Columbia is only the beginning of the problem. No state has a statute of limitations specifically applicable to treble damage suits. Therefore federal courts have had to select the state statute most nearly compatible with the supposed "nature" of the treble damage action. Almost inevitably the action for treble damages has been classified differently in different states. ${ }^{4}$ In Delaware, for instance, it becomes an "action on the case," 5 in Virginia a "tort action which survives," "while in California it is an "action upon a liability created by statute, other than a penalty or forfeiture." 7

3. One year: American Tobacco Co. v. People's Tobacco Co., Ltd., 204 Fed. 58 (5th Cir. 1913) (Louisiana statute); Northern Kentucky Tel. Co. v. Southern Bell Tel. \& Tel., 1F. Supp. 576 (E.D. Ky. 1932) (Kentucky). (Montana).

Two years: Hansen Packing Co. v. Swift \& Co., 27 F. Supp. 364 (S.D. N.Y. 1939)

Three years: Oklahoma ex rel. Phillips v. American Book Co., 144 F. 2d 585 (10th Cir. 1944) (Oklahoma); Foster \& Kleiser Co. v. Special Site Sign Co., 85 F. 2d 742 (9th Cir. 1936) (California); Williamson v. Columbia Gas \& Electric Corp., 27 F. Supp. 198 (D. Del. 1939) (Delaware); Seaboard Terminals Corp. v. Standard Oil Co. of N. J., 24 F. Supp. 1018 (S.D. N.Y. 1938) (Maryland); Harvey v. Booth Fisheries Co. of Del., 228 Fed. 782 (D. Wash. 1915) (Washington).

Four years: Ben C. Jones \& Co. v. West Publishing Co., 270 Fed. 563 (5th Cir. 1921) (Texas); Greve v. Gibraltar Enterprises, 85 F. Supp. 410 (D. N.M. 1949) (New Mexico).

Five years: Barnes Coal Corp. v. Retail Coal Merchants Ass'n., 128 F. 2d 645 (4th Cir. 1942) (Virginia); Kentucky-Tennessee Light \& Power Co. v. Nashville Coal Co., 37 F. Supp. 728 (W.D. Ky. 1941) (Kentucky).

Six years: Buckeye Powder Co. v. E. I. DuPont De Nemours Powder Co., 248 U.S. 55 (1918) (New Jersey); Bluefield S.S. Co. Ltd. v. United Fruit Co., 243 Fed. 1 (3rd Cir. 1917) (Pennsylvania); Pastor v. American Tel. \& Tel., 76 F. Supp. 781 (S.D. N.Y. 1940) (New York); Strout v. United Shoe Machinery Co., 208 Fed. 646 (D. Mass. 1913). (1906) (Tennessee).

Ten years: Chattanooga Foundry \& Pipe Works v. City of Atlanta, 203 U.S. 390

4. Even in the same state courts have involved different statutes of limitation in treble damage suits. In Northern Kentucky Tel. Co. v. Southern Bell Tel. \& Tel. Co., 1 F. Supp. 576 (E.D. Ky. 1932), aff'd, 73 F. 2d 333 (6th Cir. 1934), the court held a treble damage action alleging a conspiracy to monopolize under $\$ 1$ of the Sherman Act barred by a oneyear Kentucky limitation for actions based on conspiracy. In Kentucky-Tennessee Light \& Power Co. v. Nashville Coal Co., 37 F. Supp. 728 (W.D. Ky. 1941), on the other hand, a five year Kentucky statute for actions based upon a "liability created by statute, when no other time is fixed by the statute creating the liability," seems to have governed a treble damage suit alleging a violation of the Robinson-Patman Act. BaLdwin's Ky. REv. Stats. $\$ 413.120$ (1943) (apparently adopted).

5. Williamson v. Columbia Gas and Electric Co., 27 F. Supp. 198 (D. Del. 1939), aff'd, 110 F. 2d 15 (3rd Cir. 1939), cert. denied, 310 U.S. 639 (1940), 49 YALE L. J. 738 (1940).

6. Barnes Coal Corp. v. Retail Coal Merchants Ass'n., 128 F. 2d 645 (4th Cir. 1942). The district court had held that the treble damage suit was a tort action which does not survive. 43 F. Supp. 309 (E.D. Va. 1942), 42 CoL. L. Rev. 1346 (1942). The reversal by the court of appeals caused a five-year rather than a one-year statute to govern.

7. Burnham Chemical Co. v. Borax Consol. Ltd., 170 F. 2d 569 (9th Cir. 1948), cert. denied, 336 U.S. 924 (1949). See notes 13 and 16 infra. 
The patchwork of disparate time limitations in antitrust cases is difficult to square with the fact that a treble damage action is a remedy created by federal statute. The right to sue for injury resulting from a violation of the antitrust laws is available to every injured person regardless of the state in which he was injured. ${ }^{s}$ The application of local law to the problem of limitations, however, discriminates against the person unfortunate enough to have been injured in a state with a relatively short statutory period.

Shopping around by plaintiffs for the longest statute available has been inevitable. This is made possible by the liberal venue provisions of the antitrust law permitting actions in any district where the defendant "resides or is found or has an agent." 9 However, most states have statutes which bar actions in their own courts if the cause would have been barred in the forum where it arose. ${ }^{10}$ Not only has this merry-go-round caused the riders confusion and delay, but it has posed some perplexing problems to the courts. They have had to decide not only in what state or states the cause finally arose-a tough question given the complicated interrelations of modern business-but also what statute of that forum governs the action. ${ }^{11}$

A federal statute of limitations would eliminate the difficulties which result from relying on local law. To frame an adequate statute Congress must weigh several issues. The first is whether the period should begin to run (a) at the moment the injury is sustained; or (b) at some later date, which would take into account the fact that some types of antitrust injuries may not be discovered for many years after the injury actually occurred. A well-concealed conspiracy under the Sherman Act is one such violation; price discrimination under Section 2 of the Clayton Act to the advantage of one customer and successfully concealed from his competitor, is another. ${ }^{12}$

8. See $\$ 4$ of the Clayton Act, 38 STAT. 731 (1914), 15 U.S.C. $\S 15$ (1946): "Any person who shall be injured in his business or property by reason of anything forbidden in the antitrust laws ... shall recover threefold the damage by him sustained. . . ."

9. Ibid. The Clayton Act also provides that any suit under the antitrust laws against a corporation "may be brought not only in the judicial district whereof it is an inhabitant, but also in any district wherein it may be found or transacts business." 38 STAT. 736 (1914), 15 U.S.C. $\$ 22$ (1946). The word "business" has been liberally interpreted by the courts. See, e.g., Jeffrey-Nichols Motor Co. v. Hupp Motor Car Corp., 46 F. 2 d 623 (1st Cir. 1931) (automobile manufacturer sent a district manager into state four or five days each month, and with each car sold a distributor issued a warranty binding on the manufacturer), reversing 41 F. 2d 767 (D.C. Mass. 1930). On the venue provisions of the Clayton Act see, generally, 1 CCH TRADE REG. REP. (9th ed.) $\$ \$ 2024,2032$ (1944).

10. This is the wording of the typical statute of this type. E.g., Colorado Stat. Ann. C. $102 \S 17$ (1935); Florida STax. ANN. \$95.10 (1943). See Developments in the LawStatutes of Limitations, 63 Harv. L. REv. 1177, 1262-64 (1950); Note, 35 CoL. L. Rev. 762, 764 n.11 (1935).

11. E.g., Momand v. Universal Film Exchange, Inc., 43 F. Supp. 996 (D. Mass. 1942); Seaboard Terminals Corp. v. Standard Oil of New Jersey, 24 F. Supp. 1018 (S.D. N.Y. 1938), aff'd, 104 F. 2d 659 (2d Cir. 1939).

12. See communication to the Yale Law Journal from Mr. Walton Hamilton, dated November 30, 1950, in the Yale Law Library: "The issue of discovery will arise in only a very few cases. . . . You have mentioned as an example discrimination under the Robinson-Patman Act to the advantage of one customer and successfully concealed from his 
To avoid the rigors of an inflexible starting date, Congress might enact a relatively short statute, such as three years, commencing when the plaintiff discovered or reasonably should have discovered his injury and the illegal practices causing it. ${ }^{13}$ This would not only provide a remedy for plaintiffs

competitor. A more glaring example is a conspiracy so skillfully concealed that although the victims are suspicious of unlawful conduct they are unable to find it-or evidence necessary to a complaint which could be made to stick in court."

13. A bill introduced in Congress in 1949 by Representative Denton of Indiana contained a limited discovery provision for treble damage suits. It provided a straight six-year limitations period for all actions brought under $\$ 4$ of the Clayton Act, except that when the action was based on conspiracy the period would not begin to run until the plaintiff "discovered (or, by the exercise of reasonable diligence, should have discovered) the facts relied upon for proof of the conspiracy." H.R. 7905, 81st Cong., 2d Sess. $\$ 1$ (c) (1949). Several witnesses testified strongly in favor of this discovery provision. See Hearings before Subcommiltee of House Committee on the Judiciary on H.R. 7905, 81st Cong., 2d Sess. (1950) 59 (testimony of Walton Hamilton), 65 (statement of John C. Stedman, Antitrust Division, Department of Justice). The House Judiciary Committee, however, rejected this bill in favor of another bill, H.R. 8763 , which contained a flat six-year limitations period for all treble damage actions with no special provision for conspiracy cases. See H.R. ReP. No. 2467, 81st Cong., 2d Sess. 3-5 (1950). The Committee gave no reason for rejecting the discovery provision. H.R. 8763 passed the House, 96 CoNG. REC. 10604 (July 17, 1950), but was never reported out of the Senate Judiciary Committee.

A similar bill was introduced in the Senate by Senator Holland. S. 1910, 81st Cong., 1st Sess. (1949). This bill never passed the hearing stage. See Hearings before Subcommittee of Senate Committee on Judiciary, 81st Cong., 1st Sess. (1949).

The case discussed most prominently in both the House and Senate hearings was Burnham Chemical Co. v. Borax Consol. Ltd., 170 F. 2d 569 (9th Cir. 1948), cert. denied, 336 U.S. 924 (1949). See House Hearings, supra, at 24 (testimony of George B. Burnham, president, Burnham Chemical Co.); Senate Hearings, supra, at 3 (testimony of Thurman Arnold), 47 (testimony of Henry G. Walter, Jr., director and secretary, American Potash \& Chemical Corp.). In the Burnham case plaintiff brought a treble damage action in 1945 alleging that he had been forced out of the borax business in January 1929 by a conspiracy on the part of defendants which violated the Sherman Act. The plaintiff alleged that he had not learned of the conspiracy until the government had filed suits against most of the defendants in 1944. As to the success of plaintiff's effort to overcome a three year California statute of limitations, see note 16 infra.

For the circumstances leading up to the filing of the government suits, see the following statement of George B. Burnham: "When World War II came, the German armies swept over the Netherlands. Some bankers from the Netherlands fled to the United States to escape the Germans. Then, when we went to war with Germany these bankers told the Alien Property Custodian that the stock of the American Potash \& Chemical Corp. was not owned by them. Instead, 90.79 percent of the stock was owned by Germans. They explained that they were just dummies to hide the identity of the real owners. Therefore, since we were at war with Germany, the Custodian seized the German-owned American Potash \& Chemical Corp.

"In going through the files of the corporation, the Government discovered a contract. The contract was executed in Berlin in 1929, between the American Potash \& Chemical Corp. and the Borax Consolidated, Ltd., of London. It was alleged that these companies had agreed in the contract to control the price of borax throughout the world and keep out competition. Such an agreement was a conspiracy in restraint of trade and a violation of our antitrust laws. Therefore, the Department of Justice brought an antitrust suit against them on September 14, 1944, in the United States district court in San Francisco, Calif., entitled 
otherwise barred, but might also have some preventive effect in restraining knowing violators.

The need for a discovery provision is questionable, however. The great weight of reported antitrust experience indicates that plaintiffs are little troubled by concealment problems, and that their difficulties regarding limitations spring from other sources. ${ }^{14}$ Furthermore, except in the most obvious cases, application of a discovery provision would be costly to the parties and difficult for the courts to apply. In the absence of some compelling need, it is advisable to avoid the drawn-out court action on the ticklish questions of "diligence" and "knowledge." Whatever discovery problems exist can be adequately answered by a fairly long but inflexible period, such as six years. ${ }^{15}$ This should give the great majority of potential plaintiffs ample time to discover facts sufficient to bring an action. ${ }^{16}$

United States v. Borax Consolidated, Ltd., et al. (Criminal 28900-S and Civil 23690-G), for violating sections 1 and 2 of the Sherman Act." Senate Hearings, supra, at 74-5. In the criminal suit all defendants pleaded nolo contendere and fines totalling $\$ 153,500$ were imposed. In the civil proceeding a consent decree was entered against all defendants except one. CCH, The Federal Antitrust Laws 311-12 (1949).

Bills to provide a limitations period for treble damage suits have been reintroduced in the present Congress. H.R. 1986, 82d Cong., 1st Sess. (1951) (six years; discovery provision for conspiracy cases); H.R. 1323, 82d Cong., 1st Sess. (1951) (six years; no discovery provision).

For federal statutes containing discovery provisions of one sort or another, see Securities Act of $1933 \S 13,48$ STAT. 84 (1933), 15 U.S.C. $\S 77 \mathrm{~m}$ (1946) (action under $\S 11$ or $\$ 12$ (2) of the Act must be brought "within one year after the discovery of the untrue statement or the omission, or after such discovery should have been made by the exercise of reasonable diligence"; but in no event may a $\$ 11$ or $\$ 12$ (1) action be brought more than three years after the security was bona fide offered to the public, nor a $\$ 12(2)$ action more than three years after the sale); Securities Exchange Act $\$ 9$ (e), 48 Stat. 890, 891 (1934), 15 U.S.C. $\S 78 \mathrm{i}(\mathrm{e})(1946)$ (action must be brought "within one year after discovery of the facts constituting the violation" and within three years after the violation); $i d . \$ 18$ (c), 48 Stat. 898 (1934), 15 U.S.C. $\$ 78 \mathrm{r}$ (c) (1946) (action must be brought "within one year after the discovery of the facts constituting the cause of action" and within three years after the cause of action accrued).

14. It is, of course, impossible to appraise all treble damage experience, since some of it is not reported.

Of the reported cases, most plaintiffs barred by statutes of limitations seem to have been troubled by (a) the unavailability to them at the time they might have brought suit of the discovery aids now embodied in the Federal Rules, e.g., Burnham Chemical Co. v. Borax Consol. Ltd., 170 F. 2d 569 (9th Cir. 1948), cert. denied, 336 U.S. 924 (1949); (b) short state statutes, e.g., Northern Kentucky Tel. Co. v. Southern Bell Tel. \& Tel., 1 F. Supp. 576 (E.D. Ky. 1932), aff'd, 73 F. 2d 333 (6th Cir. 1934) (one year); (c) lack of diligence on their parts, e.g., Ben C. Jones \& Co. v. West Publishing Co., 270 Fed. 563 (5th Cir. 1921); (d) or a mistaken belief that the longer of two state statutes was applicable, e.g., Northern Ky. Tel. Co. v. Southern Bell Tel. \& Tel., supra. However, even in some of the reported cases the facts are by no means clear.

15. Roughly, the average length of the state statutes that have been construed in treble damage actions is a little over four years. See note 3 supra.

16. Finding facts and evaluating them in order to determine whether to bring an action may be particularly difficult in the antitrust field. See Hearings before Subcommittee 
Finally, Congress should recognize the correlative problems raised by Section 5 of the Clayton Act. This already suspends, during the pendency of a government action, the running of limitations on private rights of action

of Senate Committee on the Judiciary on S. 1910, 81st Cong., 1st Sess. 2-10, 16-30, 33-9, 63-4, 70-8 (1949) (testimony of Thurman Arnold and George B. Burnham).

Even if Congress enacted a statute of limitations for antitrust suits without a discovery provision, an exception for cases of "fraudulent concealment" might be read into the statute. In Holmberg v. Armbrecht, 327 U.S. 392 (1946), creditors sued in November, 1943 , to enforce the double liability of a shareholder of a joint stock land bank which had closed its doors in May, 1932. The creditors alleged that not until 1942 did they learn that Bache, the stockholder, had concealed his stock ownership under the name of Armbrecht. The Court, sustaining the plaintiff, held that in the case of a federally-created right for which the sole remedy is in equity, the federal laches doctrine supersedes the state statute of limitations. In the course of its opinion the Court stated by way of dicta: "[T]his Court long ago adopted as its own the old chancery rule that where a plaintiff has been injured by fraud and 'remains in ignorance of it without any fault or want of diligence or care on his part, the bar of the statute does not begin to run until the fraud is discovered, though there be no special circumstances or efforts on the part of the party committing the fraud to conceal it from the knowledge of the other party.' . . . This equitable doctrine is read into every federal statute of limitations. If the Federal Farm Loan Act had an explicit statute of limitations for bringing suit under $\$ 16$, the time would not have begun to run until after petitioners had discovered, or had failed in reasonable diligence to discover, the alleged deception by Bache which is the basis of this suit." Id. at 397. [Italics added.] Every case cited by the Court on this latter point, however, involved "double-barrelled" fraud-i.e., the basic cause of action was for fraud, and defendant had also concealed the facts constituting the cause of action. Exploration Co., Ltd. v. United States, 247 U.S. 435 (1918) (action to cancel land patents on ground that they had been procured from U.S. by fraud); United States v. Diamond Coal \& Coke Co., 255 U.S. 323 (1921) (same); Bailey v. Glover, 21 Wall. 342 (1874) (action to set aside a fraudulent conveyance). It seems doubtful whether the laches doctrine will be read into a federal statute of limitations governing legal actions except where there is such "double-barrelled" fraud.

In the Burnham case, supra note 13, plaintiff argued: (1) that his action was founded on a conspiracy which itself was a fraud; (2) that therefore his action, although for treble damages, was in equity; (3) that since he remained in ignorance of the fraud without any lack of diligence on his part, the three-year California statute of limitations did not begin to run until the fraud was discovered-i.e., until the government suits were filed-even if defendants had made no special effort to conceal the fraud; and (4) that defendants here had in addition "fraudulently concealed" the facts. The Ninth Circuit Court of Appeals, rejecting these contentions, held that the action was one at law, and that recovery could be had only for damages sustained within three years prior to the filing of the complaint. It agreed with the district court's finding that "from May 17, 1929 to October 10, 1939, appellant knew, or had good cause and reason to believe, that its business had been theretofore damaged and that it had been driven out of business by acts of the appellees which violated the antitrust laws of the United States; that appellant was, during this period, convinced that it had a good case against appellant for the damage it had then suffered and that its attorneys so believed and so advised it." Id. at 578. For a contrary view as to whether a "laches" doctrine may be read into a state statute of limitations in a treble damage suit, see American Tobacco Co. v. People's Tobacco Co., 204 Fed. 58 (5th Cir. 1913) (defendants' concealment of conspiracy tolled a one-year Louisiana limitations statute).

A companion case to Burnham is Suckow Borax Mines Consol. v. Borax Consolidated, Ltd., 81 F. Supp. 301 (N.D. Cal. 1948), aff'd, 185 F. 2d 196 (9th Cir. 1950), cert. denied, 19 U.S.L. WEEK 3237 (U.S. March 6, 1951).

See, generally, Dawson, Fraudulent Concealment and Statutes of Limitations, $31 \mathrm{MrcH}$. L. REv. 875 (1933). 